\title{
Analisis Kesalahan Bahasa pada Surat Dinas yang Dibuat oleh Perangkat Desa Pangebatan Kecamatan Karanglewas Kabupaten Banyumas Tahun 2019
}

\author{
Analysis on Language Error in Service Letter Made by the Pangebatan Village Apparatus of \\ Karanglewas District, Banyumas Regency Year 2019 \\ ${ }^{1 *}$ Yaumil Munawaroh, ${ }^{2)}$ Sukirno \\ ${ }^{1,2)}$ Program Studi Pendidikan Bahasa dan Sastra Indonesia \\ Universitas Muhammadiyah Purwokerto \\ *email: yaumilmunawaroh06@gmail.com, sukirnopwt56@gmail.com
}

\begin{abstract}
Histori Artikel:
ABSTRAK

Diajukan:

$13 / 03 / 2021$

Diterima:

09/07/2021

Diterbitkan:

$13 / 07 / 2021$

Penelitian ini bertujuan untuk mendeskripsikan kesalahan penggunaan ejaan, pemilihan kata, struktur kalimat, dan kata mubazir pada surat dinas yang dibuat oleh perangkat Desa Pangebatan. Penelitian ini merupakan jenis penelitian deskriptif kualitatif. Data dalam penelitian ini adalah bahasa surat dinas yang ditulis oleh perangkat desa. Sumber data dalam penelitian ini adalah surat dinas yang dibuat oleh perangkat Desa Pangebatan tahun 2019. Pengumpulan data penelitian ini digunakan teknik dokumentasi dan teknik catat. Dokumentasi berupa lembar surat dinas yang dibuat perangkat Desa Pangebatan, Teknik catat yaitu membaca dan mencatat data pada setiap surat ditinjau dari aspek kesalahan berbahasanya. Teknik analisis data digunakan teknik agih dengan mencatat secara terperinci perihal yang diteliti. Penyajian data digunakan teknik informal. Hasil penelitian ini menunjukkan bahwa kesalahan bahasa pada surat dinas yang dibuat oleh perangkat Desa Pangebatan, Kecamatan Karanglewas, Kabupaten Banyumas tahun 2019 sebanyak 1.010 kesalahan yang terdiri dari: (1) kesalahan penggunaan ejaan ditemukan sebanyak 709, (2) kesalahan pemilihan kata ditemukann sebanyak 91, (3) kesalahan struktur kalimat ditemukann sebanyak 61, (4) kesalahan penulisan kata mubazir ditemukan sebanyak 149.
\end{abstract}

Kata kunci: Bahasa; Surat Dinas; Desa Pangebatan

\begin{abstract}
This study aims to describe the use of spelling errors, word selection, sentence structure, and redundant words in official letters made by Pangebatan Village officials. This research is a type of qualitative descriptive research. The data in this study is the language of official letters written by village officials. The data source in this study was an official letter made by the Pangebatan Village apparatus in 2019. This research data collection used documentation and note-taking techniques. Documentation in the form of official letter sheets made by the Pangebatan Village apparatus, the note-taking technique is reading and recording data on each letter in terms of language errors. The data analysis technique used the agih technique by recording in detail the subject being studied. Presentation of data used informal techniques. The results of this study indicate that the language errors in official letters made by the Pangebatan Village, Karanglewas District, Banyumas Regency in 2019 were 1,010 errors consisting of: (1) spelling errors were found as many as 709, (2) errors There were 91 word selection fields, (3) 61 sentence structure errors, (4) 149 redundant word writing errors.
\end{abstract}

Keywords: Language; Official Letter; Pangebatan Village 
Yaumil Munawaroh, Sukirno

Analisis Kesalahan Bahasa pada Surat Dinas yang Dibuat oleh Perangkat Desa Pangebatan Kecamatan

Karanglewas Kabupaten Banyumas Tahun 2019

\section{PENDAHULUAN}

Bahasa merupakan alat komunikasi yang dibutuhkan dalam masyarakat untuk berinteraksi. Bahasa terdiri dari bahasa lisan dan bahasa tulisan. Bahasa lisan merupakan lambang bunyi yang diucapkan, sedangkan bahasa tulisan berbentuk huruf-huruf dan tanda baca yang dituliskan. Ragam bahasa lisan yang diungkapkan melalui media lisan, seperti berpidato, ceramah, berdialog, dan sebagainya. Sedangkan ragam bahasa tulis digunakan untuk menulis buku, makalah, skripsi, surat, dan sebagainya. Penguasaan bahasa lisan dan tulis juga sama pentingnya, perlu diperhatikan secara baik dan cermat. Salah satu bentuk alat komunikasi melalui media bahasa tulis yaitu surat. Surat terdiri dari berbagai macam jenis, yang termasuk ke dalam jenis surat yaitu surat dinas.

Surat dinas ialah alat komunikasi bahasa tulis yang berkaitan dengan kepentingan tugas dan kegiatan dinas instansi. Isi dalam surat dinas berhubungan dengan pengelolaan administrasi. Kegiatan kantor pemerintah maupun swasta tidak terlepas dari kegiatan saling memberikan informasi baik lisan maupun tulisan. Pada saat menulis surat harus memperhatikan Pedoman Umum Ejaan Bahasa Indonesia yang meliputi penggunaan huruf, penggunaan tanda baca, dan penulisan kata. Penggunaan pilihan kata dan struktur kalimat dalam menulis surat juga harus diperhatikan. Dalam menulis surat, terutama surat dinas harus memperhatikan komponen-komponen yang ada di dalam surat dinas. Hal ini dimaksudkan agar fungsi-fungsi komunikasi secara formal dapat tercapai. Salah satu instansi pemerintah yang menggunakan surat sebagai alat komunikasi adalah kantor kepala desa. Seperti yang diketahui, pemerintahan desa banyak melaksanakan kegiatan yang melibatkan semua pihak seperti rapat desa, pemilihan kepala desa, rapat LPMD, dan lain-lain. Untuk memperlancar pelaksanaan kegiatan tersebut, diperlukan media komunikasi yaitu surat. Surat berfungsi untuk menyampaikan informasi seperti perintah, pemberitahuan, tugas, permintaan, undangan, maupun teguran kepada pihak-pihak yang bersangkutan. Melihat fenomena yang terjadi saat ini di kantor pemerintahan desa. Beberapa kantor desa hanya asal membuat surat. Sekedar menyalin surat yang telah ada atau mengganti sedikit kata-kata di dalam surat. Hal ini sering dianggap sepele oleh sebagian orang. Namun, jika dilihat dan diteliti lebih jeli, ditemukan banyak kesalahan-kesalahan dalam surat tersebut. Seharusnya pemerintah desa dalam menggunakan bahasa Indonesia memberi contoh kepada masyarakat, tentang penggunaan bahasa Indonesia yang baik dan benar.

Alasan peneliti memilih judul ini karena peneliti sebagai warga masyarakat di Desa $\mathrm{Pa}$ ngebatam tertarik untuk meneliti tentang penggunaan bahasa surat dinas bagi perangkat desa. Alasan peneliti memilih desa tersebut karena sebagai warga masyarakat di Desa Pangebatan. Peneliti masih menjumpai surat yang dibuat perangkat desa ditemukan kesalahan. Alasan selanjutnya dimungkinkan perangkat desa belum menguasai tentang bahasa surat berdasarkan Pedoman Umum Ejaan Bahasa Indonesia. Terakhir peneliti sebagai mahasiswa jurusan bahasa Indonesia terpanggil untuk memperbaiki kesalahan tersebut. Peneliti mengambil surat yang telah diterbitkan pada tahun 2019 dari bulan Januari sampai Desember. Surat yang diterbitkan sebanyak 90, tetapi peneliti mengambil 40 surat. Hal ini karena beberapa surat tidak diarsipkan dan ada surat yang mempunyai perihal yang sama.

Berdasarkan latar belakang tersebut, peneliti tertarik untuk memilih judul "Analisis Kesalahan Bahasa Surat Dinas yang Dibuat oleh Perangkat Desa Pangebatan Kecamatan Karanglewas Kabupaten Banyumas Tahun 2019".

Berdasarkan latar belakang di atas rumusan masalah peneliti ini yaitu, "Bagaimanakah kesalahan ejaan, kesalahan pemilihan kata, kesalahan sturktur kalimat, dan penggunaan kata mubazir pada surat dinas yang dibuat oleh perangkat Desa Pangebatan tahun 2019.

\section{Ejaan Bahasa Indonesia}

Dalam KBBI ejaan adalah kaidahkaidah cara menggambarkan bunyi-bunyi (kata, kalimat, dan sebagainya) dalam bentuk 
tulisan (huruf- huruf) serta penggunaan tanda baca. Selaras dengan pendapat Purwandari dan Qoniah (2015:18) ejaan adalah suatu sistem aturan tentang cara menuliskan bahasa dengan menggunakan huruf, dan tanda baca sebagai sarananya sehingga jauh lebih luas dari sekedar masalah pelafalan, karena mengatur keseluruhan cara menuliskan bahasa.

Dalam PEUBI ada tiga penjelasan mengenai penggunaan huruf, penulisan kata, dan penggunaan tanda baca. Penggunaan huruf meliputi (a) huruf kapital; dan (b) huruf miring. Penulisan kata meliputi (a) kata dasar; (b) kata berimbuhan; (c) bentuk ulang; (d) kata depan; (e) singkatan; (f) angka dan bilangan. Penggunaan tanda baca meliputi (a) tanda titik; (b) tanda koma; (c) tanda titik koma; (d) tanda titik dua; (e) tanda hubung (f) tanda miring.

Berdasarkan uraian di atas dapat diambil kesimpulan ejaan merupakan segala aturan yang berkaitan dengan tata cara menuliskan bahasa. Dalam PEUBI ada tiga penjelasan mengenai aturan tersebut yaitu penggunaan huruf, penulisan kata dan penggunaan tanda baca.

\section{Pilihan Kata}

Pilihan kata merupakan ketepatan seseorang dalam memilih dan menggunakan kata sesuai dengan situasi dan kondisi (Triningsih 2018:15), sedangkan menurut Sukirno (2020:125) pilihan kata atau diksi pada dasarnya adalah hasil dari memilih kata tertentu untuk dipakai dalam suatu tuturan bahasa. Ada tiga hal penting seseorang dalam memilih kata. Pertama, kemahiran memilih kata hanya dimungkinkan bila seseorang menguasai kosakata yang cukup. Kedua, diksi atau pilihan kata yang mengandung pengertian upaya atau kemampuan membedakan secara tepat kata-kata yang memiliki nuansa makna serumpun. Ketiga, diksi atau pilihan kata menyangkut kemampuan untuk memilih kata-kata yang tepat dan cocok untuk situasi tertentu. Berdasarkan pernyataan di atas dapat disimpulkan bahwa pilihan kata atau diksi seseorang tergantung dengan kemampuan orang tersebut dalam penguasaan kata.

\section{Struktur Kalimat}

Kalimat adalah satuan bahasa terkecil yang merupakan kesatuan pikiran. Dalam bahasa lisan kalimat diawali dan diakhiri dengan kesenyapan, dalam bahasa tulis diawali dengan huruf kapital dan diakhiri dengan tanda titik, tanda seru, atau tanda tanya (Nurdjan dkk. 2016: 42-43). Sukirno (2020:145) menjelaskan kalimat adalah bagian ujaran yang mempunyai struktur minimal subjek (S) dan predikat $(\mathrm{P})$ dan intonasinya menunjukkan bagian ujaran itu sudah lengkap dengan makna. Into-nasi final kalimat dalam bahasa tulis dilambangkan dengan titik, tanda tanya, dan tanda seru.

Unsur kalimat adalah fungsi sintaksis yang dalam buku-buku tata bahasa Indonesia lama lazim disebut jabatan kata dan kini disebut peran kata dalam kalimat, yaitu Subjek $(\mathrm{S})$, predikat $(\mathrm{P})$, Objek $(\mathrm{O})$, pelengkap (Pel), dan keterangan (Ket). Kalimat bahasa Indonesia baku sekurang-kurangnya terdiri atas dua unsur, yakni subjek dan predikat (Sukirno 2020:146)

\section{Kata Mubazir}

Menurut Mustakim (2014: 57) yang dimaksud kata yang mubazir adalah kata-kata yang kehadirannya dalam konteks pemakaian bahasa tidak diperlukan. Dengan memahami kata-kata yang mubazir, pemakai bahasa dapat menghindari penggunaan kata yang tidak perlu dalam konteks tertentu. Menurut Nurdjan dkk (2016:36) kata mubazir adalah kata-kata bersinonim atau kata-kata yang sama maknanya dan digunakan bersama-sama sekaligus sehingga menjadi mubazir, yaitu menjadi berlebih- lebihan. Berdasarkan pernyataan di atas dapat disimpulkan bahwa kata mubazir merupakan kata yang tidak berguna atau berlebihan.

\section{Surat Dinas}

Surat dinas merupakan surat-surat resmi yang di dalamnya menyangkut berbagai hal tentang kedinasan (Darmawati 2008:1). Selaras dengan pendapat Ulyani (2012:8) surat dinas memiliki arti yang sangat penting, tidak hanya untuk instansi pemerintah ataupun lembaga swasta, tetapi juga dapat digunakan oleh perorangan yang 
memiliki kebutuhan penting dengan keberadaan surat dinas.

Bagian-bagian surat dinas merupakan satu kesatuan. Bagian seruta dinas terbagi menjadi 13 bagian sebagai berikut: (1) kepala surat; (2) nomor surat; tanggal surat; (4) lampiran; (5) perihal; (6) alamat tujuan; (7) salam pembuka; (8) isi; (9) salam penutup; (10) nama organisas; (11) tanda tangan; (12) tembusan; (13) inisial.

Bahasa dalam surat harus memenuhi kriteria, di antaranya: (1) Jelas dalam hal ini adalah jelas unsur-unsur subjek (S), predikat $(\mathrm{P})$, Objek (O), dan keterangan (Ket) sehingga bahasa surat terlihat memenuhi kaidah bahasa; (2) Lugas dalam hal ini berarti bahasa yang digunakan tidak menimbulkan makna ganda; (3) Komunikatif dalam hal ini merupakan menyatunya pokok pikiran pembaca surat dengan penulis surat.

\section{METODE}

Jenis penelitian yang digunakan dalam penelitian ini adalah kualitatif dengan metode deskriptif. Metode penelitian kualitatif adalah metode penelitian yang berlandaskan pada filsafat postpositivisme, digunakan untuk meneliti pada kondisi obyek yang alamiah, (sebagai lawannya adalah eksperimen) di mana peneliti adalah sebagai instrument kunci. Salim (2019:29) mengemukakan penelitian kualitatif sifatnya deskriptif analitik. Artinya data yang diperoleh seperti hasil pengamatan, hasil wawancara, hasil pemotretan, analisis dokumen, catatan langsung lapangan sisusun peneliti di lokasi penelitian, tidak dituangkan dalam bentuk angka-angka. Hasil ananlisis data berupa pemaparan mengenai situasi yang diteliti dalam bentuk urauan naratif.

Dalam penelitian ini peneliti bertujuan untuk mendeskripsikan kesalahan penulisan dan penggunaan tanda baca dalam surat dinas Kantor Desa Pangebatan.

Data dalam penelitian ini berupa bahasa surat dinas yang ditulis oleh perangkat desa yang meliputi 4; ejaan, pemilihan kata, struktur kalimat, dan kata mubazir. Sumber data penelitian ini berupa surat yang dibuat oleh perangkat Desa Pangebatan terhitung dari bulan januari sampai desember 2019 .

\section{Teknik Pengumpulan Data}

Teknik pengumpulan data merupakan langkah awal yang paling utama dalam penelitian, karena tujuan utama dari penelitian adalah mendapatkan data. Pengumpulan data pada penelitian kualitatif yang utama adalah peneliti berpartisipasi pada obyek yang diteliti, melakukan observasi langsung, wawancara mendalam dan studi dokumentasi. (Sugiyono 2019:409- 411). Dalam kaitannya dengan pengertian tersebut, pengumpulan data dalam penelitian ini dilakukan dengan teknik dokumentasi dengan teknik catat.

Menurut Sugiyono (2019: 430) dokumen merupakan catatan peristiwa yang sudah berlalu. Dokumen bisa berbentuk tulisan, gambar, atau karya-karya monumental dari seseorang. Dalam penelitian ini menggunakan teknik dokumen surat dinas yang telah diterbitkan pada tahun 2019.

\section{Teknik Analisis Data}

Menurut Sudaryanto (2015: 13) analisis data kebahasaan berarti mengurai dan (kadang-kadang) memburaikan atau menggunakan teknik agih. Namun, penguraian dan pemburaiannya itu hanyalah dengan dan dalam pikiran sang penelitinya. Dalam penelitian ini peneliti menggunakan teknik analisis triangulasi. Ada tiga tahap dalam menganalisis data yaitu reduksi data, penyajian data, dan verifikasi data.

\section{HASIL DAN PEMBAHASAN}

\section{Hasil Penelitian}

Hasil penelitian kesalahan bahasa meliputi penggunaan ejaan, pemilihan kata, struktur kalimat dan kata mubazir yang terdapat dalam 40 surat dinas.

\section{Kesalahan Penggunaan Ejaan}

Kesalahan penggunaan ejaan terdapat pada bagian kepala surat sebanyak 40 surat, perihal sebanyak 20 surat, nomor sebanyak 37 surat, Alamat tujuan sebanyak 40 surat, Salam pembuka sebanyak 7 surat, bagian isi sebanyak 35 surat, kalimat penutup sebanyak 36 surat, pengirim sebanyak 40 surat. 
Yaumil Munawaroh, Sukirno

Analisis Kesalahan Bahasa pada Surat Dinas yang Dibuat oleh Perangkat Desa Pangebatan Kecamatan

Karanglewas Kabupaten Banyumas Tahun 2019

\section{Kesalahan Pemilihan Kata}

Kesalahan pemilihan kata terdapat pada bagian isi sebanyak 15 surat dan kalimat penutup sebanyak 40 surat.

\section{Kesalahan Struktur Kalimat}

Kesalahan struktur kalimat terdapat pada bagian isi sebanyak 30 surrat dan kalimat penutup sebanyak 36 surat.

\section{Kesalahan Pengunaan Kata Mubazir}

Kesalahan penggunaan kata mubazir terdapat pada bagian kepala surat sebanyak 16 surat, tanggal surat sebanyak 40 surat, lampiran sebanyak 12 surat, alamat tujuan sebanyak 40 surat, kalimat penutup sebanyak 40 surat.

\section{PEMBAHASAN}

\section{Kesalahan Penggunaan Ejaan}

Kesalahan penggunaan ejaan meliputi kesalahan penggunaan huruf kapital, penulisan kata, dan kesalahan penggunaan tanda baca.

Kepala Surat

PEMERINTAH DESA PANGEBATAN

KECAMATAN KARANGLEWAS

KABUPATEN BANYUMAS

Jl. Raya Pengebatan Nomor 01 Telp (0281)

6840135 Kode Pos 53161

Pada data di atas terjadi kesalahan penulisan kata, yaitu singkatan pada bagian kepala surat. Singkatan kata yang sesungguhnya kata-kata itu tidak perlu disingkat. Pada penulisan alamat kop surat seharusnya tidak perlu disingkat. Hal ini sesuai dengan kaidah penulisan surat yang baik dan benar. Sehingga, penulisan yang benar kata $\mathrm{Jl}$. menjadi Jalan. Berikut ini peneliti paparkan perbaikan kata tersebut.

PEMERINTAH DESA PANGEBATAN

KECAMATAN KARANGLEWAS

KABUPATEN BANYUMAS

Jalan Raya Pengebatan Nomor 01 Telpon

(0281) 6840135 Kode Pos 53161

Nomor Surat

Nomor : 005 / 3 / 2019
Pada data di atas terjadi kesalahan penulisan garis miring, yaitu pada nomor surat. Penulisan garis miring seharusnya tidak dengan spasi. Seharusnya garing miring langsung angka tanda dispasi. Dalam penulisan tersebut sebaiknya tanda garis miring tanpa spasi sesuai dalam Pedoman Umum Ejaan Bahasa Indonesia.

Nomor : 005/3/2019

Perihal Surat

Perihal: SOSIALISASI RENCANA PROYEK PENGEBORAN AIR TANAH PDAM

Pada perihal surat di atas terjadi kesalahan penulisan huruf, yaitu kata SOSIALISASI RENCANA PROYEK PENGEBORAN AIR TANAH PDAM.

Dalam penulisan perihal surat tidak lazim jika ditulis menggunakan huruf besar semua, melainkan hanya pada huruf awalnya saja dan tidak menggunakan tanda baca garis bawah pada perihal surat. Berikut ini peneliti paparkan perbaikan kalimat tersebut.

Perihal: Sosialisasi Rencana Proyek Pengeboran Air Tanah PDAM

Alamat Tujuan

Bpk. ALI UMAR BASALAMAH

Selaku Pemilik dan Pimpinan PT

Bima Agung Damar Buana di

PURWOKERTO

Pada alamat tujuan surat di atas (S:12) terjadi kesalahan penulisan huruf, yaitu pada nama orang ALI UMAR BASALAMAH. Nama tersebut seharusnya tidak menggunakan huruf kapital semua, karena di dalam Pedoman Umum Ejaan Bahasa Indonesia nama orang hanya awal saja yang menggunakan huruf kapital. Terjadi kesalahan pada kata PURWOKERTO seharusnya pada huruf awal saja yang menggunakan huruf kapital. Dalam Pedoman Umum Ejaan Bahasa Indonesia dijelaskan bahwa nama geografi hanya huruf awal yang menggunakan huruf kapital. Penulisan tersebut tidak sesuai. 
Yaumil Munawaroh, Sukirno

Analisis Kesalahan Bahasa pada Surat Dinas yang Dibuat oleh Perangkat Desa Pangebatan Kecamatan

Karanglewas Kabupaten Banyumas Tahun 2019

Pengirim Surat

Pj. Kepala Desa Pangebatan

\section{SUYANTO}

NIP. 1966093019900311010

Pada data di atas di atas terjadi kesalahan penulisan huruf, yaitu penulisan huruf kapital pada bagian nama pengirim surat. Nama tersebut seharusnya tidak menggunakan huruf kapital semua, karena di dalam Pedoman Umum Ejaan Bahasa Indonesia nama orang hanya awal saja yang menggunakan huruf kapital. Agar kata tersebut menjadi benar, maka perlu perbaikan. Sehingga, penulisan yang benar nama tersebut menjadi Suyanto.

Pada data di atas terjadi kesalahan penggunaan tanda baca, yaitu tanda koma pada bagian nama pengirim surat. Pada kalimat Kepala Desa Pangebatan seharusnya menggunakan tanda koma setelah kalimat tersebut. Dalam Pedoman Umum Ejaan Bahasa Indonesia tanda koma dipakai untuk mengapit keterangan tambahan yang sifatnya tidak membatasi. Berikut ini peneliti paparkan perbaikan bagian pengirim surat di atas.

Pj. Kepala Desa Pangebatan,

Suyanto

NIP 1966093019900311010

\section{Kesalahan Pemilihan Kata}

Kesalahan pemilihan kata yang terjadi pada surat dinas yang dibuat oleh perangkat Desa Pangebatan tahun 2019 terdapat kesalahan pada penggunaan kata. Kesalahan kata tersebut disebabkan adanya kata yang tidak serasi dan tidak tepat didalam kalimat. Seharusnya, kata tersebut tidak digunakan agar tidak menimbulkan kesalahpahaman pembaca.

\section{Isi Surat}

(1) Sehubungan dengan hal tersebut mohon dengan hormat atas kehadirannya pada pertemuan yang akan dilaksanakan dengan ketentuan sebagai berikut:
Pada data di atas terjadi kesalahan pemilihan kata ganti -nya kurang tepat dalam kalimat. Kata ganti - nya seharusnya diganti dengan kata Bapak/Ibu/Saudara. Karena kata ganti -nya dalam data di atas tidak jelas mengacu kepada siapa. Bentuk -nya itu lebih tepat jika diganti dengan kata sapaan untuk orang kedua. Sehingga kata ganti -nya diganti dengan kata ganti sapaan Bapak/Ibu/Saudara. Karena komunikasi yang terjadi di dalam surat ialah komunikasi antara pihak pertama dan kedua. Berikut ini peneliti paparkan perbaikan kalimat di atas.

(1a) Sehubungan dengan hal tersebut, mohon dengan hormat atas kehadiran Bapak/Ibu/Saudara pada pertemuan yang akan dilaksanakan sebagai berikut:

\section{Kalimat Penutup}

(2) Demikian atas kehadirannya dan kerjasamanya disampaikan terima kasih. Pada data di atas terjadi kesalahan pemilihan kata disampaikan kurang tepat dalam kalimat.

Kata disampaikan dalam KBBI memiliki arti menyampaikan. Kata disampaikan mestinya diikuti kata oleh siapa yang menyampaikan. Hal ini akan menimbulkan kesalahpahaman pembaca terhadap isi kalimat. Kata disampaikan lebih tepat jika diganti dengan kata ucapkan apabila kita menekankan pada keinginan untuk mengucapkan sesuatu. Berikut ini peneliti paparkan perbaikan kalimat di atas.

(2a) Demikian atas kehadiran dan kerjasama Bapak/Ibu/Saudara, kami ucapkan terima kasih.

\section{Kesalahan Struktur Kalimat}

Kesalahan struktur kalimat terjadi pada surat dinas yang dibuat oleh perangkat Desa Pangebatan tahun 2019 terdapat kesalahan pada unsur kalimatnya. Kesalahan kalimat tersebut disebabkan adanya kalimat yang terlalu panjang dan tidak lengkap sesuai unsur kalimat. Berikut ini peneliti paparkan kalimat yang mengandung kesalahan struktur kalimat yang terjadi dalam surat. 
(1) Dengan ini mohon dengan hormat atas kehadirannya pada pertemuan yang akan dilaksanakan dengan ketentuan sebagai berikut:

Pada data kalimat di atas terdapat kesalahan unsur kalimat. Kalimat di atas belum ada subjek kalimat yang menunjukkan pelaku atau tokoh. Unsur kalimat di atas seharusnya diberi subjek sehingga kalimatnya menjadi jelas. Berikut penjelasan unsur kalimat di atas.

Dengan ini mohon dengan hormat

Ket atas kehadirannya pada pertemuan

PO yang akan dilaksanakan dengan

Ket ketentuan sebagai berikut:

Kalimat di atas berpola Ket-P-Ket, seharusnya kalimat dasar minimal terdiri dari subjek dan predikat. Pembahasan kata ganti nya telah dijelaskan dalam pemilihan kata. Seharusnya kalimat di atas diberi subjek agar sesuai dengan pola kalimat dasar. Berikut ini peneliti paparkan perbaikan kalimat di atas.

Kami mohon dengan hormat atas $\mathrm{S}$ Ket kehadiran Bapak/Ibu pada pertemuan P S O yang akan dilaksanakan sebagai Ket berikut:

\section{Kata Mubazir}

Pada surat dinas yang dibuat oleh perangkat Desa Pangebatan Kecamatan Karanglewas Kabupaten Banyumas tahun 2019 yang peneliti analisis ada empat puluh surat yang digunakan, terdapat beberapa kesalahan penggunaan kata mubazir. Berikut ini peneliti paparkan kalimat yang mengandung kesalahan penulisan kata mubazir yang terjadi pada beberapa bagian surat.

Kepala Surat

PEMERINTAH DESA PANGEBATAN

KECAMATAN KARANGLEWAS

KABUPATEN BANYUMAS

Alamat Jalan Raya Pengebatan Nomor 01 Telp (0281) 6840135 Kode Pos 53161
Kesalahan penulisan kata mubazir terjadi pada penulisan alamat yang diikuti alamat lengkap. Pada data di atas terjadi kemubaziran kata, yaitu pada kata Alamat. Kemubaziran itu terjadi karena pada kop surat sudah dicantumkan alamat lengkap tanpa harus diperjelas dengan kata alamat. Penulisan yang benar cukup ditulis jalan, telpon, dan kode pos.

Sehingga pada data di atas terjadi kemubaziran kata alamat. Perbaikan dari data di atas sebagai berikut.

\section{PEMERINTAH DESA PANGEBATAN \\ KECAMATAN KARANGLEWAS KABUPATEN BANYUMAS}

Jalan Raya Pengebatan Nomor 01 Telp (0281) 6840135 Kode Pos 53161

Tanggal Surat

Pangebatan, 3 Januari 2019

Kesalahan penulisan kata mubazir terjadi pada penulisan tanggal yang diikuti nama suatu wilayah, hal itu terlihat pada keseluruhan surat. Pada data di atas terjadi kemubaziran kata, yaitu pada kata Pangebatan. Kemubaziran itu terjadi karena pada kop surat sudah dicantumkan nama kota tempat kantor berada. Penulisan yang benar cukup ditulis tanggalnya saja. Sehingga pada data di atas terjadi pengulangan pencantuman nama kota. Perbaikan dari data di atas sebagai berikut.

\section{Januari 2019}

\section{Lampiran}

Lampiran : 1 (satu) bendel

Kesalahan penulisan kata mubazir terjadi pada penulisan lampiran yang diikuti penulisan angka dalam huruf.. Pada data di atas terjadi kemubaziran kata, yaitu pada kata satu. Kemubaziran itu terjadi karena pada lampiran sudah dicantumkan jumlah lampiran tanpa harus ditulis dalam huruf. Penulisan yang benar cukup ditulis salah satu saja. Sehingga pada data di atas terjadi pengulangan pencantuman jumlah lampiran. Perbaikan dari data di atas sebagai berikut. 
Yaumil Munawaroh, Sukirno

Analisis Kesalahan Bahasa pada Surat Dinas yang Dibuat oleh Perangkat Desa Pangebatan Kecamatan

Karanglewas Kabupaten Banyumas Tahun 2019

Lampiran $\quad: 1$ bendel

Kalimat Penutup

Demikian atas kehadirannya dan kerjasamanya disampaikan termia kasih.

Kesalahan penulisan kata mubazir terjadi pada penulisan kata Demikian hal itu terlihat pada keseluruhan surat. Pada data di atas terjadi kemubaziran kata, yaitu pada kata demikian. Kemubaziran itu terjadi karena walaupun kata itu tidak dicantumkan, tidak mengubah arti dalam kalimat tersebut. Sehingga penulisan kata demikian tidak perlu dicantumkan dalam salam penutup. Penulisan yang benar cukup langsung ditulis kata atas. Pembahasan pemilihan kata ganti dan penulisan ejaan sudah dijelaskan. Perbaikan dari data di atas sebagai berikut.

Atas kehadiran dan kerjasama Bapak/Ibu/Saudara, kami ucapkan terima kasih.

\section{KESIMPULAN}

Berdasarkan hasil penelitian kesa-lahan bahasa yang telah peneliti lakukan pada 40 surat dinas yang dibuat oleh perangkat Desa Pangebatan Kecamatan Karang $\neg$ lewas Kabupaten Banyumas tahun 2019, maka dapat disimpulkan sebagai berikut.

1. Kesalahan penggunaan ejaan ditemu $\neg$ kan sebanyak 709 yang terdiri dari penggunaan huruf kapital pada awal kata dan nama orang, penulisan kata dasar, dan penggunaan tanda baca seperti titik dua, koma, garis miring, dan sebagainya.

2. Kesalahan pemilihan kata ditemukann sebanyak 91 yang terdiri dari pemilihan kata ganti orang yang tidak tepat dan pemilihan kata yang kurang tepat.

3. Kesalahan struktur kalimat ditemukan sebanyak 61 yang terdiri dari kalimat yang tidak lengkap dan kalimat yang terlalu panjang.

4. Kesalahan penggunaan kata mubazir ditemukan sebanyak 149 yang terdiri dari penulisan tanggal surat, lampiran, alamat tujuan, dan kalimat penutup. Berdasarkan data kesalahan di atas dapat diketahui bahwa dari
40 surat dinas tersebut terdapat 1.010 kesalahan.

Saran

Berdasarkan hasil penelitian kesalahan bahasa yang telah dilakukan, peneliti menyampai-kan saran sebagai berikut.

1. Bagi perangkat Desa Pangebatan

Kecamatan Karanglewas Kabupaten

Banyumas disarankan untuk

memperhatikan beberapa hal, yaitu perlu mengadakan pemeriksaan kembali secara teliti terhadap surat dinas yang telah dibuat, perangkat desa lebih terbuka dalam pembuatan surat, dan sebelum surat di tanda tangani sebaiknya konsep surat didiskusikan jika ditemukan kesalahan.

2. Bagi perangkat Desa Pangebatan Kecamatan Karanglewas Kabupaten Banyumas perlu mendapatkan pelatihan mengenai penulisan surat dinas.

\section{DAFTAR PUSTAKA}

Darmawati, Uti. (2018). Surat Surat Dinas. Klaten: PT Intan Pariwara Ejaan (Def 2.3) (n.d). Dalam Kamus Besar Bahasa Indonesia Edisi V. Diakes pada ponsel pinter. Pada 10 Juli 2020

Mustakim. (2014). Seri Penyuluhan Bentuk dan Pilihan Kata. Jakarta. Diakses di http://badanbahasa.kemdikbud.go.id/ lamanbahasa/ node/49. Pada 8 Desember 2020.

Nurdjan dkk. (2016). Bahasa Indonesia untuk Perguruan Tinggi. Makasar: Aksara Timur. Diakses di https://www. coursehero.com/file/ 47779769/MKDU-Bahasa-

Purwandari, Retno dan Qoni'ah. (2015). Buku Pintar Bahasa Indonesia. Yogyakarta: Familia

Sukirno. (2020). Bahasa Indonesia Untuk Mahasiswa Non Jurusan Bahasa. Yogyakarta: Pustaka Pelajar

Sudaryanto (2015). Metode Dan Teknik Analisis Bahasa. Yogyakarta: Sanata Dharma University Press. 
Yaumil Munawaroh, Sukirno

Analisis Kesalahan Bahasa pada Surat Dinas yang Dibuat oleh Perangkat Desa Pangebatan Kecamatan

Karanglewas Kabupaten Banyumas Tahun 2019

Sugiyono.(2019).Metode

Penelitian

Pendidikan. Bandung: ALFABETA.

Salim dan Haidir. (2019). Penelitian

Pendidikan. Jakarta: Kencana.

Triningsih, Diah Erna. (2018). Diksi (Pilihan

Kata). Klaten: PT Intan Pariwara

Ulyani, Mara. (2012). Buku Lengkap

Aneka Surat Dinas. Yogyakarta:

FlashBooks. 